\title{
Embedding gender factor in energy input-output analysis of paddy production systems in Mazandaran Province, Iran
}

\author{
Anahita Valiollahi Bisheh ${ }^{1} \cdot$ Hadi Veisi ${ }^{2} \cdot$ Homan Liaghati $^{2} \cdot$ \\ Abdol Majid Mahdavi Damghani ${ }^{2} \cdot$ Jafar Kambouzia $^{2}$ \\ ${ }^{1}$ Agriculture Faculty, Ferdowsi University of Mashhad, Mashhad, Iran \\ ${ }^{2}$ Environmental Sciences Research Institute, Shahid Beheshti University, Tehran, Iran
}

Received: 20 October 2016/Revised: 23 January 2017/Accepted: 28 February 2017/Published online: 11 March 2017 (C) Joint Center on Global Change and Earth System Science of the University of Maryland and Beijing Normal University and Springer-Verlag Berlin Heidelberg 2017

\begin{abstract}
This study explores gender in the energy inputoutput analysis by comparing the energy indicators in paddy production in female-headed farms and male-headed farms during years of 2014-2015 in Mazandaran Province. Questionnaires were used to collect data from 120 paddy farmers (60 males and 60 females). Energy indicators were calculated for female- and male-headed farms. Results revealed noticeable variations in some important energy indicators between female- and male-headed farms. A significant difference was observed in terms of total energy input. The majority of energy input consumption for both female- and male-headed farms was devoted to diesel fuel, fertilizers, especially nitrogen fertilizers, and machinery. Results indicated that there was no significant difference between male-headed and female-headed farms in terms of net energy and specific energy, but energy use efficiency and energy productivity were significantly higher for female-headed farms. Then, it can be argued that gender factor had a significant impact on amount of direct, indirect, and renewable energy inputs. Based on our findings, female-headed rice systems were more efficient, where fossil-based inputs were used more environment friendly
\end{abstract}

Hadi Veisi

h_veisi@sbu.ac.ir; hveisi@gmail.com

Anahita Valiollahi Bisheh

anahita.valiollahi@yahoo.com

Homan Liaghati

h-liaghati@sbu.ac.ir

Abdol Majid Mahdavi Damghani

mahdavi.a@sbu.ac.ir

Jafar Kambouzia

J_kambouzia@sbu.ac.ir than male-headed farms. Finally, targeted "soft" policies like gender-sensitive capacity-developing program were proposed.

Keywords Gender · Energy · Efficiency · Productivity · Agriculture

\section{Introduction}

Despite many attempts to specify the energy use efficiency in different agro-ecosystems (Bockari-Gevao et al. 2005; Kazemi et al. 2015; Keshavarz Afshar et al. 2013; NabaviPelesaraei et al. 2014; Pishgar-Komleh et al. 2011; Rafiee et al. 2010), the gap of gender perspective in this kind of analysis has not been filled yet. This ignorance happened while the role of women in crop production has been considered as the foundation of studies regarding women's participation in the development process since 1970s (e.g., Barrientos et al. 2005; Birah et al. 2016; Carr 2005; Egharevba and Iweze 2004; Jha 2004; Kerr et al. 2007; Lope-Alzina 2007). Women provide half of the world food production and agricultural labor (FAO 2009), while they have a limited access to essential production resources, such as land, labor, and inputs (FAO 2010; World Bank 2007). Fuentes and Wiig (2009) declared that land ownership and women's access to it have a close and direct relationship with energy use efficiency. Therefore, it is obvious that gender factor can widely ridge individuals' access to resources and their interactions with nature. It is also estimated that if rural women like men have an appropriate access to agricultural inputs, the yield of agricultural products can increase by $2.5 \%$ in developing 
countries and the number of total hungers across the world will decrease by 12-17\% (FAO 2011). After decades of research, it is clear that women and men have a wide range of profits and priorities related to the issue of sustainability affected by multiple factors (Meinzen-Dick et al. 2014).

Although different studies (e.g., Barrientos et al. 2005; Birah et al. 2016; Carr 2005; Egharevba and Iweze 2004; Jha 2004; Kerr et al. 2007; Lope-Alzina 2007) provide valuable information regarding the role of women in agroecosystems sustainability, the wide gap in gender-based energy analysis has not been noted yet. This ignorance is not rational, while the excessive energy usage (Roy et al. 2009; Tandon and Singh 2009) in agro-ecosystems has profound and alarming effects on the environment and human health (Haas et al. 2001; Ju et al. 2009; Wood et al. 2006; Zhang et al. 2013). This is important then to examine the role of gender in agro-ecosystems' sustainability concerning energy analysis in particular for rice production where women role is critical. In this sense, in Iran, where about 2.35 million tons of paddy were produced in 2014-2015, about $77.21 \%$ of the total paddy production is supplied by three Northern provinces (Gilan, Mazandaran, and Golestan) (Ministry of Jihad-e-Agriculture 2015), and based on informal statistics, more than half of the paddy labor is covered by women. However, previous studies about energy analysis of rice production (Alipour et al. 2012; Cherati et al. 2011; Pishgar-Komleh et al. 2011) have ignored the effective role of women in this important crop production, while their practices in rice production systems with respect to many social, economic, and ecological issues are different. Therefore, the aim of this study is to probe the quantity of energy used for paddy production in female-headed and male-headed rice farms and the comparison of energy use pattern between them in Mazandaran Province of Iran.

\section{Materials and methods}

\subsection{Study area}

This study was conducted in Mazandaran Province (Babol County), Iran, in 2014-2015 production year. Mazandaran is located between $35^{\circ} 46^{\prime}$ and $36^{\circ} 58^{\prime}$ Lat. $\mathrm{N}$ and between $50^{\circ} 21^{\prime}$ and $54^{\circ} 08^{\prime}$ Lon. Table 1 displays the climatic variables and soil properties of the study region which has mild and humid climate due to $653.40 \mathrm{~mm}(\mathrm{~mm})$ precipitation, $78 \%$ relative humidity, and $17.40{ }^{\circ} \mathrm{C}$ average temperature. The sunshine hours, a general indicator of cloudiness of a location, are 1898.80 in this region. The soil texture of the study area is silt loam categorized as a moderate texture with 10-35\% clay. Organic carbon (OC) is $1.3 \%$ in this region soil which shows that there is the proper amount of organic matter in the soil. The amount of phosphorus and potassium in the soil of the study area is 9.0 and $125.0 \mathrm{ppm}$, respectively. They are necessary macronutrients for the plant growth. Potential of hydrogen $(\mathrm{pH})$ is a numeric scale used to specify the acidity or basicity of an aqueous solution. The soil $\mathrm{pH}$ is 7.4 in the study area. Solutions with $\mathrm{pH}$ less than 7 are acidic, and solutions with $\mathrm{pH}$ greater than 7 are basic. The soil electrical conductivity (EC), a measure of the amount of salts in soil, is $2.1 \mathrm{dS} \mathrm{m}^{-1}$ in the study area soil (Kazemi et al. 2015).

Mazandaran Province was selected because of its vast rice-cultivated area. In Iran, this province, along with two other Northern provinces (Gilan and Golestan), supplied about $77.21 \%$ of the total paddy production in 2014-2015 (Ministry of Jihad-e-Agriculture 2015). Based on the informal statistics, women carry out more than half of the rice cultivation operations, i.e., mainly sterilizing seeds, seeding in treasury, transplanting, care nursery, weeding, fertilizing, spraying, harvesting, and transporting products to warehouse.

\subsection{Data collection}

The sample size constituted 120 respondents involving males and females from five villages. It was estimated by means of a formula adopted from Noordzij et al. (2010) where random sampling was employed to obtain a sample size of 120 rice growing households from five selected villages at confidence level of $95 \%$ and level of precision of 5\%. Bailey (1994) stated that 30 cases are a simple minimum for studies in which statistical data analysis is to be done regardless of their population size. A total of 120 respondents were from a list of female-headed as well as male-headed households selected randomly. The five randomly selected villages were picked from two purposively selected wards of Babol County which were famous for rice production. Because we needed women who had the power and opportunity of making decisions on managing rice farms, especially on using energy inputs, it was preferred that all women in this study were widows and divorced women. Rural women (especially married women) mostly participate in rice production systems to provide labor force for various processes of rice production systems, rather than being given the chance of deciding about the use of agricultural inputs. They will mostly get the opportunity to personally manage the household farms after their divorce or spouses' death. Even in such circumstances due to cultural, economic, and social barriers women are often placed in a lower priority than other male relatives (brother, father, and else) to manage farms. Despite women, the marital status of men does not often affect their cash crop production systems management, 
Table 1 Average soil properties and annual average of climatic variables in Mazandaran Province, Iran

\begin{tabular}{lcccc}
\hline Potential of hydrogen $(\mathrm{pH})$ & Electrical conductivity $(\mathrm{EC})$ & Potassium $(\mathrm{K})$ & Phosphorous $(\mathrm{P})$ & Organic carbon $(\mathrm{OC})$ \\
\hline 7.4 & $2.1 \mathrm{dS} \mathrm{m}^{-1}$ & $125.0 \mathrm{ppm}$ & $9.0 \mathrm{ppm}$ & $1.3 \%$ \\
\hline Dominate class of texture & Precipitation & Temperature & Sunshine hours & Relative humidity \\
\hline Silt loam & $653.40 \mathrm{~mm}$ & $17.40{ }^{\circ} \mathrm{C}$ & $1898.80 \mathrm{~h}$ & $78 \%$ \\
\hline
\end{tabular}

Kazemi et al. (2015)

because men are placed in a higher priority than women to make decisions about household farms activities. The data were collected through questionnaire survey to femaleheaded and male-headed households which were designed for this purpose to cover a sample of 60 male-headed household respondents (comprising husband respondents) and 60 female-headed household respondents. All inputs and outputs of rice production were analyzed using SPSS software. Descriptive and inferential statistical treatments such as percentages, means, and Student's t test were applied to the data.

\subsection{Energy analysis}

All the detailed data from questionnaire were averaged and arranged. First, all inputs and outputs for paddy production were determined, quantified, entered into SPSS (var. 2012), and then transformed into energy units and expressed in mega joule per hectare $\left(\mathrm{MJ} \mathrm{ha}^{-1}\right)$.

In this province, energy inputs for the paddy production were irrigation water, seed, human labor, diesel fuel, machinery, pesticides, and fertilizers; while energy outputs were paddy and straw. It must be noted that solar energy, either as radiation or as heat, was not taken into account, as it is considered a free subsidy in the energetic or economic analysis of agricultural systems (Tabar et al. 2010; Rafiee et al. 2010; An 2011). The energy equivalent of inputs and outputs, shown in Table 2, was used to estimate the energy values. Energy inputs in agricultural systems can be divided into direct and indirect or renewable and non-renewable forms. The sources of direct energy include human labor, diesel fuel, and irrigation water, while indirect energy sources include chemical fertilizers, manure, pesticides, seed, and machinery. Renewable energy consists of human labor, manure, seed, and irrigation water; and nonrenewable energy sources consist of machinery, diesel fuel, pesticides, and chemical fertilizers. The energy use efficiency, energy productivity, specific energy, and net energy were calculated using the total energy equivalent of inputs and outputs per unit (MJ ha $\left.{ }^{-1}\right)$ and paddy yield $\left(\mathrm{kg} \mathrm{ha}^{-1}\right)$, applying the following equations (Demircan et al. 2006; Tabatabaeefar et al. 2009):
1. Energy use efficiency $=$ Total energy output $\left(\mathrm{MJ} \mathrm{ha}^{-1}\right) /$ Total energy input $\left(\mathrm{MJ} \mathrm{ha}^{-1}\right)$.

2. Energy productivity $=$ Grain output $\left(\mathrm{kg} \mathrm{ha}^{-1}\right) /$ Total energy input (MJ ha ${ }^{-1}$ ).

3. Specific energy $=$ Total energy input $\left(\mathrm{MJ} \mathrm{ha}^{-1}\right) / \mathrm{Grain}$ output $\left(\mathrm{kg} \mathrm{ha}^{-1}\right)$.

4. Net energy $=$ Energy output $\left(\mathrm{MJ} \mathrm{ha}^{-1}\right)-$ Energy input $\left(\mathrm{MJ} \mathrm{ha}^{-1}\right)$.

\section{Results and discussion}

\subsection{Demographic information and economic condition}

Based on outcomes displayed in Table 3, there was no significant difference between male and female farmers in terms of age (the average age of men $=51.65$ years old and the average age of women $=53.15$ years old). Results showed that few farmers $(20 \%$ of men and $11.7 \%$ of women) were younger than 40 years old. OECD (2001) reported that the farmers were mostly older than 55 years old and only a few farmers had less than 35 years in many OECD countries. Mojarradi et al. (2008) indicated that the majority $(23.4 \%)$ of farmers belonged to the age category of 41-50 years old. Despite the fact that the face of agricultural workforce gets old, agricultural sector cannot disregard younger and well-educated farmers because they can better adapt themselves to variations of financial and environmental conditions (OECD 2001). Our findings disclosed that women farmers highly suffered from poor education conditions. Most of them $(65 \%)$ were educated up to analphabetic level, whereas just only a few (16.7\%) men farmers belonged to this educational category. It is obvious that inappropriate educational conditions among women, compared with men, restrict their enterprise options and limit their ability to take up vocational and technical trainings (World Bank 2009). Tatlidil et al. (2009) demonstrated that the better education was considered as one of the most effective factors in promotion of the awareness about sustainable agricultural practices. 
Table 2 Energy equivalent of inputs and outputs in agricultural production

\begin{tabular}{llll}
\hline Particulars & Unit & Energy equivalents (MJ unit ${ }^{-1}$ ) & Reference \\
\hline $\begin{array}{l}\text { Human labor } \\
\text { Fertilizers }\end{array}$ & $\mathrm{h}$ & 1.96 & AghaAlikhani et al. (2013) and Kazemi et al. (2015) \\
Nitrogen $(\mathrm{N})$ & $\mathrm{kg}$ & 78.1 & \\
Phosphate $\left(\mathrm{P}_{2} \mathrm{O}_{5}\right)$ & $\mathrm{kg}$ & 17.4 & Pishgar-Komleh et al. (2011) \\
Potassium $\left(\mathrm{K}_{2} \mathrm{O}\right)$ & $\mathrm{kg}$ & 13.7 & Pishgar-Komleh et al. (2011) \\
Manure & $\mathrm{kg}$ & 0.3 & Pishgar-Komleh et al. (2011) \\
Pesticides & $\mathrm{kg}$ & 229 & Rafiee et al. (2010) \\
Insecticides & $\mathrm{kg}$ & 115 & \\
Fungicides & $\mathrm{kg}$ & 85 & Pishgar-Komleh et al. (2011) \\
Herbicides & $\mathrm{L}$ & 56.31 & Pishgar-Komleh et al. (2011) \\
Diesel fuel & $\mathrm{h}$ & 62.7 & Pishgar-Komleh et al. (2011) \\
Machinery & $\mathrm{m}$ & 1.02 & AghaAlikhani et al. (2013) and Kazemi et al. (2015) \\
Irrigation water & $\mathrm{kg}$ & 14.7 & AghaAlikhani et al. (2013) and Kazemi et al. (2015) \\
Seed & $\mathrm{MJ}$ & - & AghaAlikhani et al. (2013) and Kazemi et al. (2015) \\
Total energy input & $\mathrm{kg}$ & 12.5 & AghaAlikhani et al. (2013) and Kazemi et al. (2015) \\
Straw & $\mathrm{kg}$ & 14.7 & - \\
Paddy & $\mathrm{MJ}$ & - & AghaAlikhani et al. (2013) and Kazemi et al. (2015) \\
Total energy output & & & AghaAlikhani et al. (2013) and Kazemi et al. (2015) \\
\hline & & - &
\end{tabular}

According to the results, men farmers had bigger family size (3.67) than women farmers (2.67). This significant difference between men and women in terms of family size may make male farmers profit from more labors. Results showed that the availability of financial credits was considerably poor in both men and women groups, but female farmers were even in a worse condition, i.e., $75 \%$ of women famers suffered from a very low availability of financial credits. Parveen (2008) reported that there were many obstacles toward women's access to credit and productive resources in Bangladesh which is due to the lack of technical knowledge, restrictions on land ownership, heavy housework, and other social and cultural circumscriptions. With respect to the on-farm income, there was a significant variation between men and women farmers (male on-farm income $=3201.44 \$$ and female on-farm income $=$ $1102.92 \$$ ). A total of $58.3 \%$ of women earned lower than $1000 \$$ on-farm income, while $43.3 \%$ of men earned more than $3000 \$$ on-farm income. This difference strongly was related to their farm size which was 0.78 ha for men and 0.48 ha for women. Horrell and Krishnan (2007) stated that female-headed households' income in Zimbabwe was 3/4 of male-headed households' income. Dadzie and Dasmani (2010) demonstrated that men farmers also benefited from much more off-farm income than women farmers in Ghana. They expressed that male farmers had a stronger tendency to reinvest their on-farm income compared with female farmers.

\subsection{Energy inputs and outputs}

Table 4 represents the average energy consumption of each input and output for paddy production in both femaleheaded and male-headed farms. The total average of energy input and output was computed 74,166.71 and 108,441.40 $\mathrm{MJ} \mathrm{ha}^{-1}$ in female-headed farms and $85,898.22$ and $112,812.08 \mathrm{MJ} \mathrm{ha}^{-1}$ in male-headed farms, respectively. The results demonstrated a significant difference between female-headed and male-headed farms in terms of the total energy input. The reason for this difference could be related to the fact FAO (2010) noted, i.e., women do not have equal access to inputs and production factors because of being subjected to more social and economic constraints than men are. Because of high tendency of paddy farmers (men and women) to plant highyield variety of rice, there is no significant difference between female-headed and male-headed farms with respect to energy output. Thapa (2008) reported that utilizing high-yield seed significantly turns up more yield per hectare. The use of fuel energy was 30,156.01 and 32,752.85 $\mathrm{MJ} \mathrm{ha}^{-1}$ in female-headed and male-headed farms, respectively. According to the data collected from studied farms, in terms of fuel consumption, there was a significant difference between female-headed and maleheaded farms. The data analysis showed that the highest energy use in rice agro-ecosystems belonged to fuel energy input, which allocated 40.66 and $38.13 \%$ of the total 
Table 3 Demographic information and economic condition of women and men farmers

\begin{tabular}{|c|c|c|c|c|c|c|c|c|}
\hline & \multicolumn{4}{|l|}{ Men } & \multicolumn{4}{|l|}{ Women } \\
\hline & Frequency & Percent & Mean & Frequency & Percent & Mean & Student's $t$ test & Sig. $(P=0.05)$ \\
\hline \multicolumn{9}{|c|}{ Availability of financial credits } \\
\hline Very low & 34 & 56.7 & - & 45 & 75 & - & - & - \\
\hline Low & 17 & 28.3 & & 13 & 21.7 & & & \\
\hline Medium & 7 & 11.7 & & 2 & 3.3 & & & \\
\hline High & 1 & 1.7 & & 0 & 0 & & & \\
\hline Very High & 1 & 1.7 & & 0 & 0 & & & \\
\hline Total & 60 & 100 & & 60 & 100 & & & \\
\hline \multicolumn{9}{|l|}{ Education } \\
\hline Illiterate & 10 & 16.7 & - & 39 & 65 & - & - & - \\
\hline No diploma degree & 35 & 58.3 & & 20 & 33.3 & & & \\
\hline Diploma degree & 12 & 20 & & 1 & 1.7 & & & \\
\hline University degree & 3 & 5 & & 0 & 0 & & & \\
\hline Total & 60 & 100 & & 60 & 100 & & & \\
\hline \multicolumn{9}{|l|}{ Age } \\
\hline $40 \geq$ & 12 & 20 & 51.65 & 7 & 11.7 & 53.15 & 0.736 & 0.463 \\
\hline $41-55$ & 26 & 43.3 & & 28 & 46.7 & & & \\
\hline $56 \leq$ & 22 & 36.7 & & 25 & 41.7 & & & \\
\hline Total & 60 & 100 & & 60 & 100 & & & \\
\hline \multicolumn{9}{|l|}{ Family size } \\
\hline 2 persons $\geq$ & 14 & 23.3 & 3.67 & 29 & 48.3 & 2.67 & 3.868 & 0.000 \\
\hline 3-4 persons & 33 & 55 & & 25 & 41.7 & & & \\
\hline 5 persons $\leq$ & 13 & 21.7 & & 5 & 10 & & & \\
\hline Total & 60 & 100 & & 60 & 100 & & & \\
\hline \multicolumn{9}{|c|}{ On-farm income per year } \\
\hline $1000 \$ \geq$ & 15 & 25 & 3201.44 & 35 & 58.3 & 1102.92 & 5.215 & 0.000 \\
\hline $1000-3000 \$$ & 19 & 31.7 & & 22 & 36.7 & & & \\
\hline $3000 \$<$ & 26 & 43.3 & & 3 & 5 & & & \\
\hline Total & 60 & 100 & & 60 & 100 & & & \\
\hline
\end{tabular}

energy consumption in female-headed and male-headed farms, respectively (Fig. 1). Results of other studies (AghaAlikhani et al. 2013; Bautista and Minowa 2010; Bockari-Gevao et al. 2005; Cherati et al. 2011; Kazemi et al. 2015; Pishgar-Komleh et al. 2011) confirmed that the fuel input has an important and effective share among all types of energy used for the paddy production. Kazemi et al. (2015) reported that the high fuel consumption in agricultural systems of Iran is due to two main reasons: old machineries and irrigation pumps. They expressed that one of the principal reasons for the high utilization of fuel is a temporal depreciation of machinery. Applying new machineries and irrigation pumps with more energy use efficiency decreases the amount of energy usage.

Fuel energy was followed by the fertilizers (including N, $\mathrm{P}_{2} \mathrm{O}_{5}, \mathrm{~K}_{2} \mathrm{O}$, and manure) energy with the share of 23.73 and $28.93 \%$ of the total energy input in female-headed and male-headed farms (Fig. 1). This outcome was in accordance with many researches (AghaAlikhani et al. 2013; Bautista and Minowa 2010; Bockari-Gevao et al. 2005; Cherati et al. 2011; Keshavarz Afshar et al. 2013) which reported fertilizers, especially chemical fertilizers, had a high consumption in paddy farms. Although the use of fertilizers, except phosphorus fertilizer, significantly varied among female-headed and male-headed farms, the energy usage of fertilizers, particularly nitrogen fertilizer, was too high in male-headed farms $\left(15,625.18 \mathrm{MJ} \mathrm{ha}^{-1}\right.$ in female-headed farms and $22,147.98 \mathrm{MJ} \mathrm{ha}^{-1}$ in maleheaded farms; Table 4). Because phosphorus causes development of strong and extensive roots, tight and thick stems, grain filling, the increase in quantity of production, and acceleration of crop growth, paddy farmers (men and women) always try to use enough phosphorus fertilizer. Kazemi et al. (2015) noted in their study that because the 
Table 4 Amounts of input and output and their energy equivalent in paddy production systems

\begin{tabular}{|c|c|c|c|c|c|c|c|}
\hline \multirow[t]{2}{*}{ Input and output } & \multirow[t]{2}{*}{ Unit } & \multicolumn{2}{|c|}{ Quantity per unit area (ha) } & \multicolumn{2}{|c|}{ Total energy equivalent $\left(\mathrm{MJ} \mathrm{ha}^{-1}\right)$} & \multirow{2}{*}{$\begin{array}{l}\text { Student's } \\
t \text { test }\end{array}$} & \multirow{2}{*}{$\begin{array}{l}\text { Sig. } \\
(P=0.05)\end{array}$} \\
\hline & & $\begin{array}{l}\text { Male-headed } \\
\text { farms }\end{array}$ & $\begin{array}{l}\text { Female-headed } \\
\text { farms }\end{array}$ & Male-headed farms & $\begin{array}{l}\text { Female-headed } \\
\text { farms }\end{array}$ & & \\
\hline Human labor & $\mathrm{h}$ & 163.61 & 239.83 & $320.68(0.37 \%)$ & $470.08(0.63 \%)$ & 3.054 & 0.003 \\
\hline Fertilizers & $\mathrm{kg}$ & 671.96 & 401.88 & $24,849.07(28.93 \%)$ & $17,598.91(23.73 \%)$ & 3.895 & 0.000 \\
\hline Nitrogen $(\mathrm{N})$ & $\mathrm{kg}$ & 283.58 & 200.07 & $22,147.98(25.78 \%)$ & $15,625.18(21.07 \%)$ & 3.736 & 0.000 \\
\hline Phosphorous $\left(\mathrm{P}_{2} \mathrm{O}_{5}\right)$ & $\mathrm{kg}$ & 95.27 & 92.91 & $1657.71(1.93 \%)$ & $1616.56(2.18 \%)$ & 0.175 & 0.861 \\
\hline Potassium $\left(\mathrm{K}_{2} \mathrm{O}\right)$ & $\mathrm{kg}$ & 71.30 & 24.22 & $976.83(1.14 \%)$ & $331.76(0.45 \%)$ & 3.707 & 0.000 \\
\hline Manure & $\mathrm{kg}$ & 221.80 & 84.69 & $66.54(0.08 \%)$ & $25.41(0.03 \%)$ & 3.152 & 0.002 \\
\hline Pesticides & $\mathrm{kg}$ & 10.96 & 7.66 & $1608.38(1.87 \%)$ & $1096.58(1.48 \%)$ & 5.285 & 0.000 \\
\hline Insecticide & $\mathrm{kg}$ & 4.19 & 2.79 & $959.71(1.12 \%)$ & $638.55(0.86 \%)$ & 3.923 & 0.000 \\
\hline Fungicide & $\mathrm{kg}$ & 2.45 & 1.46 & $281.31(0.33 \%)$ & $167.48(0.23 \%)$ & 3.172 & 0.002 \\
\hline Herbicide & $\mathrm{kg}$ & 4.32 & 3.42 & $367.37(0.43 \%)$ & $290.54(0.39 \%)$ & 3.459 & 0.001 \\
\hline Diesel Fuel & $\mathrm{L}$ & 581.65 & 535.54 & $32,752.85(38.13 \%)$ & $30,156.01(40.66 \%)$ & 4.732 & 0.000 \\
\hline Machinery & $\mathrm{h}$ & 275.37 & 253.23 & $17,265.79(20.10 \%)$ & $15,877.32(21.41 \%)$ & 5.245 & 0.000 \\
\hline Irrigation water & $\mathrm{m}^{3}$ & 7989.27 & 7648.06 & $8149.05(9.49 \%)$ & $7801.02(10.52 \%)$ & 1.934 & 0.056 \\
\hline Seed & $\mathrm{kg}$ & 64.79 & 79.37 & $952.39(1.11 \%)$ & $1166.79(1.57 \%)$ & 2.734 & 0.008 \\
\hline Total energy input & MJ & & & $85,898.22(100 \%)$ & $74,166.71(100 \%)$ & 5.359 & 0.000 \\
\hline Straw & $\mathrm{kg}$ & 2567.57 & 2405.10 & $32,094.58(28.45 \%)$ & $30,063.75(27.72 \%)$ & 1.091 & 0.277 \\
\hline Paddy & $\mathrm{kg}$ & 5490.99 & 5331.81 & $80,717.50(71.55 \%)$ & $78,377.65(72.28 \%)$ & 0.497 & 0.620 \\
\hline Total energy output & MJ & & & $112,812.08(100 \%)$ & $108,441.40(100 \%)$ & 0.667 & 0.506 \\
\hline
\end{tabular}

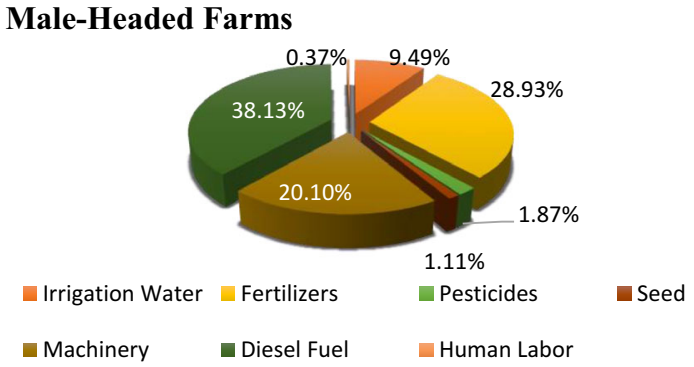

Female-Headed Farms

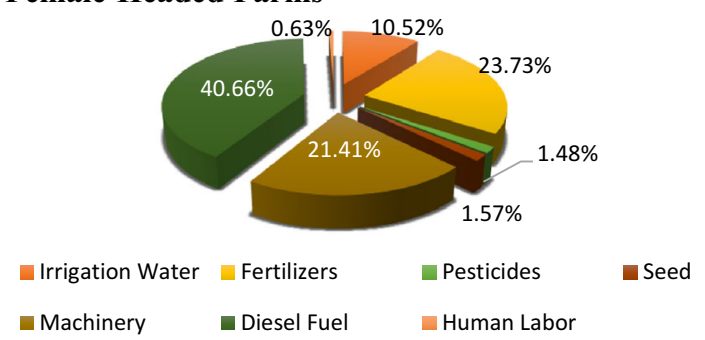

Fig. 1 Share of energy inputs for paddy production in female-headed and male-headed farms

energy use efficiency in the fields of Mazandaran is low due to the excessive consumption of fertilizers, fertilization should be reduced and optimized in this region. PishgarKomleh et al. (2011) noted two remarkable reasons for the high consumption of fertilizers in Iran: farmers' low knowledge and subsidies price. Regarding the lack of knowledge and ineffective policies and programs of the Ministry of Agriculture Jihad, most of Iranian farmers do not have accurate information about the required quantity of fertilizers in different agro-ecosystems. This in turn promotes a prevalent opinion between them that the extreme use of fertilizers will increase the yield (Chauhan et al. 2006). In addition, the subsidies price of government has a considerable effect on fertilizers' consumption. Gladwin (1992) indicated farmers had less access to credit, especially women suffered more losses due to the removal of subsidies and the increase in fertilizers' prices. Therefore, the subsidy adjustment policies resulted in much more reduction in fertilizers' usage in female-headed farms than male-headed farms. In general, the energy management in rice agro-ecosystems, especially in female-headed agroecosystems, because of their ecology friendly attitude and reduced fertilizers and fuel consumption, is momentous. Optimizing fertilizers' usage in rice farms not only brings financial gains to farmers, but also can decrease environmental pollutions. Appropriate fertilization management, integrating a legume into the crop rotation, application of composts, chopped residues, and other soil managements can decrease the chemical fertilizers energy consumption (Nabavi-Pelesaraei et al. 2014). Hence, it is essential to focus more on fertilizers and fuel usage than other inputs, because these two factors efficiently reduce energy use in rice farms (Kazemi et al. 2015). 
According to the data collected from studied farms, in terms of pesticide consumption, there was a significant difference between female-headed and male-headed farms. The amount of herbicides, fungicides, and insecticides consumption was calculated 290.54, 167.48, and 638.55 $\mathrm{MJ} \mathrm{ha}^{-1}$ in female-headed farms and 367.37, 281.31, and $959.71 \mathrm{MJ} \mathrm{ha}^{-1}$ in male-headed farms, respectively (Table 4). Women were less reliant on excessive use of pesticides in pest control. This can be because women are more sensitive to environment and health of their family, more associated with pesticides risks, more aware of alternative methods of pest control such as the use of beneficial insects than men (Birah et al. 2016). Of course, it is necessary to mention the high prices of pesticides and low access of women to them, i.e., effective in reducing the consumption of this type of energy input (Doss and Morris 2000).

The results showed that 239.83 and $163.61 \mathrm{~h}$ of human labor and 253.23 and $275.37 \mathrm{~h}$ of machine power were required per hectare in female-headed and male-headed farms, respectively (Table 4). There was a significant difference between female-headed and male-headed farms with respect to human labor energy and machinery energy consumption. Higher amount of the energy input of human labor in female-headed farms can be connected to two factors: more management of weeds due to less consumption of herbicides and their limited access to machinery (mover and planter machines). The amount of seed energy consumption was, respectively, 1166.79 and 952.39 $\mathrm{MJ} \mathrm{ha}^{-1}$ in female-headed and male-headed farms. The usage of seed energy was higher in female-headed farms, because women often have low access to appropriate seed (FAO 2010). The required amount of seed can be decreased by improving its quality, which in turn reduces the energy waste. On the other hand, using the high-quality seed will help reducing the chances of pest and weed infestation and thus increasing the yield (Pishgar-Komleh et al. 2011). There was no significant difference between female-headed and male-headed farms with respect to water energy input. The energy consumption of water was calculated 7801.02 and $8149.05 \mathrm{MJ} \mathrm{ha}^{-1}$ in female-headed and male-headed farms, respectively.

\subsection{Energy indicators}

Energy use efficiency, specific energy, net energy, and energy productivity in female-headed and male-headed farms are tabulated in Table 5. Energy use efficiency is one of the best energy indices showing how efficient the energy has been used in paddy production. The average of energy use efficiency was, respectively, 1.48 and 1.30 in femaleheaded and male-headed farms. Due to the high consumption of energy inputs, especially fertilizers in rice farms of Northern provinces (Gilan, Mazandaran, and Golestan) of Iran (Kazemi et al. 2015), the energy use efficiency estimate was lower in this study area. PishgarKomleh et al. (2011) revealed that the energy ratio in rice farms of Gilan Province, Iran, was 1.53. AghaAlikhani et al. (2013) stated that the energy use efficiency was 1.72 in the traditional production system and 1.63 in the mechanized production system in Mazandaran. Rice production system ranges among the most energy-consuming crop production systems (Pimentel 2009). Energy input: output ratio of rice cultivated in some developing countries such as Valley of Garhwal (India), Malaysia, and Bangladesh were reported 1:0.79, 1:8.86, and 1:4.6-1:6.5, while this ratio was 1:1.42 in USA (Deutsche Gesellschaft für and Internationale Zusammenarbeit (GIZ) GmbH 2013). Although the energy use efficiency was low in the studied farms, and on the other hand, this indicator is very determining in environmental studies due to the excessive input usage, women farmers were able to achieve more energy output per each used energy unit and thus performed more efficiently in terms of energy consumption. Therefore, increasing the annual yield of paddy production and/or reducing the energy usage, particularly diesel fuel energy and fertilizers, would help optimizing the rice agroecosystems energy consumption. Many researchers

Table 5 Energy indicators in paddy production systems

\begin{tabular}{llcccc}
\hline Parameters & Unit & Quantity & Student's $t$ test & Sig. $(P=0.05)$ \\
\cline { 2 - 5 } & & Male-headed farms & Female-headed farms & & \\
\hline Total energy input & $\mathrm{MJ} \mathrm{ha}^{-1}$ & $85,898.22$ & $74,166.71$ & 5.359 & 0.000 \\
Total energy output & $\mathrm{MJ} \mathrm{ha}^{-1}$ & $112,812.08$ & $108,441.40$ & 0.667 & 0.506 \\
Net energy & $\mathrm{MJ} \mathrm{ha}^{-1}$ & $26,913.86$ & $34,274.70$ & 1.253 & 0.213 \\
Specific energy & $\mathrm{MJ} \mathrm{kg}^{-1}$ & 16.69 & 1.352 & 0.179 \\
Energy use efficiency & - & 1.30 & 0.07 & 2.167 & 0.033 \\
Energy productivity & $\mathrm{kg} \mathrm{MJ}^{-1}$ & 0.06 & 2.343 & 0.021 \\
\hline
\end{tabular}




\section{Size Farm (hectare)}

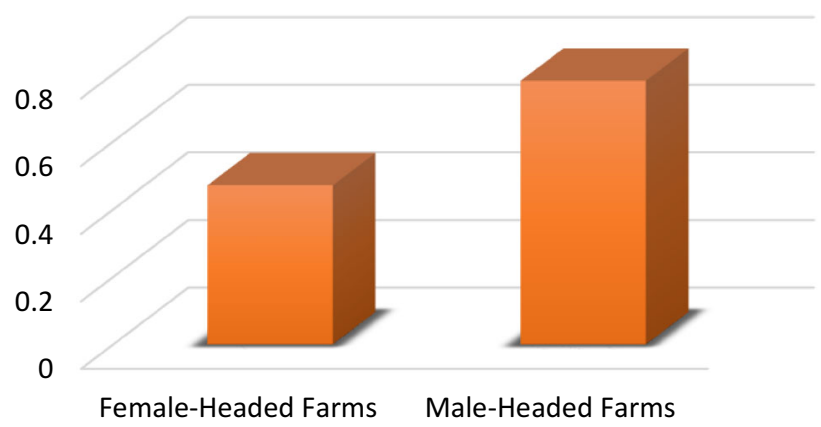

Fig. 2 Average size of female-headed and male-headed rice farms

reported that applying sound farming management practices such as crop rotation and cultivating legumes improves energy use efficiency (Pishgar-Komleh et al. 2011; Rathke et al. 2007).

In this study, there was a significant difference between women and men farmers with respect to farm size $(P<0.05)$. As shown in Fig. 2, the average size of femaleheaded and male-headed farms was 0.47 and 0.78 ha, respectively. In terms of farm size effect on energy use efficiency, Iqbal (2007) and Nassiri and Singh (2009) indicated that small rice farms had the highest energy use efficiency and the lowest specific energy in comparison with other groups. Pishgar-Komleh et al. (2011) reported that the largest farm size group had higher energy ratio compared with medium and small farms. Therefore, one of the main factors that affect the energy use efficiency in paddy production systems can be the farm size which is smaller for women farmers than men farmers. In general, environmental constraints such as a combination of unsuitable land, weed and pest attack, bad weather, planting delay, and infertile soils significantly reduce crop yield and its energy efficiency (Rahman and Hasan 2014).

The energy productivity (the total yield obtained per unit of energy input) was lower in male-headed farms than female-headed farms (Table 5). The average energy productivity was $0.07 \mathrm{~kg} \mathrm{MJ}^{-1}$ in female-headed farms and $0.06 \mathrm{~kg} \mathrm{MJ}^{-1}$ in male-headed farms. The calculation of energy productivity rate is well documented in the literature such as stake tomato (1.0) (Esengun et al. 2007), cotton (0.06) (Yilmaz et al. 2005), sugar beet (1.53) (Erdal et al. 2007). The energy productivity is a measure of the environmental effects associated with the production crops. This variable can therefore be used to identify the optimum intensity of land and management from an ecologicalfriendly attitude (Hülsbergen et al. 2001). According to the calculated productivity indicator, women farmers took advantage of more ecological viewpoints in managing their paddy production systems than men farmers. The specific energy and net energy were calculated 15.47 and
34,274.70 $\mathrm{MJ} \mathrm{ha}^{-1}$ in female-headed farms and 16.69 and 26,913.86 $\mathrm{MJ} \mathrm{ha}^{-1}$ in male-headed farms, respectively (Table 5). Although there was no significant difference between female-headed and male-headed farms with respect to the specific energy and net energy, women farmers used energy for paddy production more efficiently. Kazemi et al. (2015) in their study in north of Iran, indicated that the lowest net energy corresponded to Mazandaran $\left(25,795.39 \mathrm{MJ} \mathrm{ha}^{-1}\right)$. Canakci et al. (2005) has also reported the specific energy for field crops and vegetable production in Turkey as $5.24 \mathrm{MJ} \mathrm{kg}^{-1}$ for wheat, $11.24 \mathrm{MJ} \mathrm{kg}^{-1}$ for cotton, $3.88 \mathrm{MJ} \mathrm{kg}^{-1}$ for maize, $16.21 \mathrm{MJ} \mathrm{kg}^{-1}$ for sesame, $1.14 \mathrm{MJ} \mathrm{kg}^{-1}$ for tomato, $0.98 \mathrm{MJ} \mathrm{kg}^{-1}$ for melon, and $0.97 \mathrm{MJ} \mathrm{kg}^{-1}$ for watermelon.

The results indicated a low level of energy efficiency and productivity in Iran agro-ecosystems in accordance with the finding of other researchers (Banaeian and Zangeneh 2011; Kazemi et al. 2015; Mohammadi et al. 2008). Banaeian and Zangeneh (2011) stated that the energy wastage in Iran agro-ecosystems reached from 8816.26 to 26,151.94 $\mathrm{MJ} \mathrm{ha}^{-1}$ during 2001-2007. Hence, there was a vast unreleased potential for improving energy use efficiency of paddy production in the region. Mousavi-Avval et al. (2011) proposed that for improving energy use efficiency in Iran, the farmers should be educated regarding the optimal use of inputs such as fertilizers, pesticides, and irrigation water as well as technologies. On the other hand, local agricultural institutes play a fundamental role to notify the farmers in terms of more efficient use of energy resources and increasing the sustainability level of agricultural production systems in the region.

\subsection{Energy forms}

Table 6 shows the distribution of total energy input as renewable, non-renewable, direct, and indirect forms. According to the obtained results, the direct energy usage was, respectively, 51.81 and $47.99 \%$ of the total energy input in female-headed and male-headed farms, while the share of indirect energy was 48.19 and $52.01 \%$ in femaleheaded and male-headed farms, respectively. Furthermore, 87.24 and $88.95 \%$ of all energy inputs in female-headed and male-headed farms was related to the non-renewable energy, while the share of renewable energy was calculated 12.76 and $11.05 \%$ in female-headed and male-headed farms, respectively. With respect to direct, indirect, and non-renewable energy usage, there was a significant difference between female-headed and male-headed farms. This means that female-headed farms were more environment friendly than male-headed farms. Several studies illustrated that the share of non-renewable energy of total energy input is much more than the share of renewable 
Table 6 Total energy input and related components in the form of direct, indirect, renewable, and non-renewable energy for paddy production systems

\begin{tabular}{|c|c|c|c|c|}
\hline \multirow[t]{2}{*}{ Energy input components } & \multicolumn{2}{|l|}{ Quantity } & \multirow[t]{2}{*}{ Student's $t$ test } & \multirow[t]{2}{*}{ Sig. $(P=0.05)$} \\
\hline & Male-headed farms & Female-headed farms & & \\
\hline Total energy input $\left(\mathrm{MJ} \mathrm{ha}^{-1}\right)$ & $85,898.22(100 \%)$ & $74,166.71(100 \%)$ & 5.359 & 0.000 \\
\hline Direct energy $^{\mathrm{a}}\left(\mathrm{MJ} \mathrm{ha}^{-1}\right)$ & $41,222.58(47.99 \%)$ & $38,427.10(51.81 \%)$ & 4.567 & 0.000 \\
\hline Indirect energy $^{\mathrm{b}}\left(\mathrm{MJ} \mathrm{ha}^{-1}\right)$ & $44,675.64(52.01 \%)$ & $35,739.61(48.19 \%)$ & 4.564 & 0.000 \\
\hline Renewable energy $^{\mathrm{c}}\left(\mathrm{MJ} \mathrm{ha}^{-1}\right)$ & $9488.67(11.05 \%)$ & $9463.29(12.76 \%)$ & 0.118 & 0.906 \\
\hline Non-renewable energy ${ }^{\mathrm{d}}\left(\mathrm{MJ} \mathrm{ha}^{-1}\right)$ & $76,409.56(88.95 \%)$ & $64,703.41(87.24 \%)$ & 5.513 & 0.000 \\
\hline
\end{tabular}

${ }^{a}$ Includes human labor, diesel fuel, and irrigation water energy sources

b Includes chemical fertilizers, manure, seed, pesticides, and machinery energy sources

c Includes human labor, seed, manure, and irrigation water

${ }^{\mathrm{d}}$ Includes diesel fuel, pesticides, chemical fertilizers, and machinery

energy (AghaAlikhani et al. 2013; Erdal et al. 2007; Mohammadi and Omid 2010; Pishgar-Komleh et al. 2011; Rafiee et al. 2010).

\section{Conclusions}

In Iran, although many researches have been conducted to determine the energy use efficiency in paddy production systems, there is no study as yet regarding the effect of paddy farmers' gender on energy indicators. This study investigated the effect of gender on energy flow in rice farms of Mazandaran Province (Babol County). The total energy input and output were 74,166.71 and 108,441.40 $\mathrm{MJ} \mathrm{ha}^{-1}$ in female-headed farms and 85,898.22 and $112,812.08 \mathrm{MJ} \mathrm{ha}^{-1}$ in male-headed farms, respectively. The analysis of energy consumption for the paddy crop in female-headed and male-headed farms demonstrated that the energy input of diesel fuel, fertilizers, and machinery in both farms of men and women had the largest share of energy input from the total energy input. The energy use efficiency was higher in female-headed farms and varied from 1.48 for farms of women to 1.30 for male-headed farms.

Results revealed that although the energy productivity was significantly different between female-headed and male-headed farms, this index in rice farms like most Iran agro-ecosystems was in a low level. Regarding the low level of energy productivity in Iran agro-ecosystems, it can be caused by old and worn-out electric and diesel pumps, excessive machinery traffic in agro-ecosystems, the lack of attention to pest and soil analysis, and the relatively low price of diesel fuel. All these deficiencies lead to excessive and non-normative fuel, fertilizers, and chemicals consumption, which ultimately incurred higher energy consumption per unit of area, reducing energy efficiency and energy productivity.

Regarding the sustainable and efficient energy consumption in agricultural systems, one of the most important and most influential factors is farmers' gender. Although women in terms of access to land, inputs, extension services, and financial credit face many constraints, according to the results of this study women paddy farmers in energy consumption compared with their counterparts performed more efficiently. Furthermore, the way women used inputs such as fertilizers and pesticides clearly demonstrated their ecological-friendly attitude and behavior. In other words, the attitude of using environment friendly and knowledge of women farmers are an effective leverage that policy makers will be able to benefit from to organize the state dysfunctional culture boom in the energy system and consequently reduce the risk of environmental crisis that has enveloped the country ecosystems.

However, one should not forget that women environment-friendly understanding and awareness would be fully useful when their social and economic concerns be reduced and their livelihoods and families under their supervision guaranteed. In this regard, targeted policies, such as providing training on ways to improve the performance and the use of new technologies and rural micro-funds, will have a great influence on women's empowerment. Of course, it is important and should be considered that the prerequisite for achieving the goals of sustainable development in every field is modifying and changing three aspects of cognitive (mental), structural (laws, regulations, etc.), and functional (objective-executive) community relation with the gender issue.

\section{References}

AghaAlikhani M, Kazemi-Poshtmasari H, Habibzadeh F (2013) Energy use pattern in rice production: a case study from Mazandaran province, Iran. Energy Convers Manag 69:157-162

Alipour A, Veisi H, Darijani F, Mirbagheri B, Behbahani A (2012) Study and determination of energy consumption to produce conventional rice of the Guilan province. Res Agric Eng 58(3):99-106 
An AKCAOZ (2011) Analysis of energy use for banana production: a case study from Turkey. Afr J Agric Res 6(25):5618-5624

Bailey BK (1994) Methods of social research. The Free Press CllierMacMilan Publishers, New York

Banaeian N, Zangeneh M (2011) Study on energy efficiency in corn production of Iran. Energy 36(8):5394-5402

Barrientos S, Kritzinger A, Opondo M, Smith S (2005) Gender, work and vulnerability in African horticulture. IDS Bull 36(2):74-79

Bautista EG, Minowa T (2010) Analysis of the energy for different rice production systems in the Philippines. Philipp Agric Sci 93(3):346-357

Birah A, Srivastava R, Chand S, Ahmed SZ (2016) Role of Women in Pest Management in Andaman. Indian Res J Ext Educ 11(21):79-82

Bockari-Gevao SM, bin Wan Ismail WI, Yahya A, Wan CC (2005) Analysis of energy consumption in lowland rice-based cropping system of Malaysia. Energy 27(4):820

Canakci M, Topakci M, Akinci I, Ozmerzi A (2005) Energy use pattern of some field crops and vegetable production: case study for Antalya Region, Turkey. Energy Convers Manag 46(4):655-666

Carr ER (2005) Development and the household: missing the point? GeoJournal 62(1-2):71-83

Chauhan NS, Mohapatra PK, Pandey KP (2006) Improving energy productivity in paddy production through benchmarking-an application of data envelopment analysis. Energy Convers Manag 47(9):1063-1085

Cherati FE, Bahrami H, Asakereh A (2011) Energy survey of mechanized and traditional rice production system in Mazandaran Province of Iran. Afr J Agric Res 6(11):2565-2570

Dadzie SK, Dasmani I (2010) Gender difference and farm level efficiency: metafrontier production function approach. J Dev Agric Econ 2(12):441-451

Demircan V, Ekinci K, Keener HM, Akbolat D, Ekinci C (2006) Energy and economic analysis of sweet cherry production in Turkey: a case study from Isparta province. Energy Convers Manag 47(13):1761-1769

Deutsche Gesellschaft für and Internationale Zusammenarbeit (GIZ) $\mathrm{GmbH}$ (2013) Rice cropping systems and resource efficiency. https://www.giz.de/fachexpertise/downloads/giz2013-en-studyrice-cropping-sys-low-res

Doss CR, Morris ML (2000) How does gender affect the adoption of agricultural innovations? Agric Econ 25(1):27-39

Egharevba RK, Iweze FA (2004) Sustainable agriculture and rural women: crop production and accompanied health hazards on women farmers in six rural communities in Edo State Nigeria. J Sustain Agric 24(1):39-51

Erdal G, Esengün K, Erdal H, Gündüz O (2007) Energy use and economical analysis of sugar beet production in Tokat province of Turkey. Energy 32(1):35-41

Esengun K, Gündüz O, Erdal G (2007) Input-output energy analysis in dry apricot production of Turkey. Energy Convers Manag 48(2):592-598

FAO (2009) Bridging the gap: FAO's programme for gender equality in agriculture and rural development. Food and Agriculture Organization of the United Nations (FAO), Rome

FAO (2010) Gender and food security-agriculture-statistics. Food and Agriculture Organization of the United Nations (FAO), Rome

FAO (2011) The state of food and agriculture 2011-women in agriculture: closing the gender gap for development. Food and Agriculture Organization of the United Nations (FAO), Rome

Fuentes, D. O., and Wiig, H. (2009). Closing the gender land gap-the effects of land-titling for women in Peru. Paper presented at the Norwegian Institute of Urban and Regional Research. Conference Paper, Oslo
Gladwin CH (1992) Gendered impacts of fertilizer subsidy removal programs in Malawi and Cameroon. Agric Econ 7(2):141-153

Haas G, Wetterich F, Köpke U (2001) Comparing intensive, extensified and organic grassland farming in southern Germany by process life cycle assessment. Agric Ecosyst Environ 83(1):43-53

Horrell S, Krishnan P (2007) Poverty and productivity in femaleheaded households in Zimbabwe. J Dev Stud 43(8):1351-1380

Hülsbergen K-J, Feil B, Biermann S, Rathke G-W, Kalk W-D, Diepenbrock W (2001) A method of energy balancing in crop production and its application in a long-term fertilizer trial. Agric Ecosyst Environ 86(3):303-321

Iqbal MT (2007) Energy input and output for production of boro rice in Bangladesh. EJEAFChe 6(5):2144-2149

Jha N (2004) Gender and decision making in Balinese agriculture. Am Ethnol 31(4):552-572

Ju X-T, Xing G-X, Chen X-P, Zhang S-L, Zhang L-J, Liu X-J, Cui Z-L, Yin B, Christie P, Zhu Z-L (2009) Reducing environmental risk by improving $\mathrm{N}$ management in intensive Chinese agricultural systems. Proc Natl Acad Sci 106(9):3041-3046

Kazemi H, Kamkar B, Lakzaei S, Badsar M, Shahbyki M (2015) Energy flow analysis for rice production in different geographical regions of Iran. Energy 84:390-396

Kerr RB, Snapp S, Chirwa M, Shumba L, Msachi R (2007) Participatory research on legume diversification with Malawian smallholder farmers for improved human nutrition and soil fertility. Exp Agric 43(04):437-453

Keshavarz Afshar R, Alipour A, Hashemi M, Ansari M, Pimentel JD (2013) Energy inputs-yield relationship and sensitivity analysis of pistachio (Pistacia vera $\mathrm{L}$.) production in Markazi Region of Iran. Span J Agric Res 11(3):661-669

Lope-Alzina DG (2007) Gendered production spaces and crop varietal selection: case study in Yucatán, Mexico. Singap J Trop Geogr 28(1):21-38

Meinzen-Dick R, Kovarik C, Quisumbing AR (2014) Gender and sustainability. Annu Rev Environ Resour 39(1):29

Ministry of Jihad-e-Agriculture (2015) Statistics report of 2014-2015 years. Statistics and Information Office of Jihad-e-Agriculture Iran, Tehran

Mohammadi A, Omid M (2010) Economical analysis and relation between energy inputs and yield of greenhouse cucumber production in Iran. Appl Energy 87(1):191-196

Mohammadi A, Tabatabaeefar A, Shahin S, Rafiee S, Keyhani A (2008) Energy use and economical analysis of potato production in Iran a case study: Ardabil province. Energy Convers Manag 49(12):3566-3570

Mojarradi G, Zamani G, Zarafshani K (2008) Analysis of factors influencing farmers' attitude towards private crop insurer using path analysis. Am Eurasian J Agric Environ Sci 3(2):247-252

Mousavi-Avval SH, Rafiee S, Jafari A, Mohammadi A (2011) Optimization of energy consumption for soybean production using data envelopment analysis (DEA) approach. Appl Energy 88(11):3765-3772

Nabavi-Pelesaraei A, Abdi R, Rafiee S, Taromi K (2014) Applying data envelopment analysis approach to improve energy efficiency and reduce greenhouse gas emission of rice production. Eng Agric Environ Food 7(4):155-162

Nassiri SM, Singh S (2009) Study on energy use efficiency for paddy crop using data envelopment analysis (DEA) technique. Appl Energy 86(7):1320-1325

Noordzij M, Tripepi G, Dekker FW, Zoccali C, Tanck MW, Jager KJ (2010) Sample size calculations: basic principles and common pitfalls. Nephrol Dial Transplant 25(5):1388-1393

OECD (2001) Environmental indicators for agriculture. http://www. oecd.org/tad/sustainableagriculture/40680869 
Parveen S (2008) Access of rural women to productive resources in Bangladesh: a pillar for promoting their empowerment. Int $\mathbf{J}$ Rural Stud 15(1):1-8

Pimentel D (2009) Environmental and economic costs of the application of pesticides primarily in the United States. In: Integrated pest management: innovation-development process. Springer, pp 89-111

Pishgar-Komleh S, Sefeedpari P, Rafiee S (2011) Energy and economic analysis of rice production under different farm levels in Guilan province of Iran. Energy 36(10):5824-5831

Rafiee S, Avval SHM, Mohammadi A (2010) Modeling and sensitivity analysis of energy inputs for apple production in Iran. Energy 35(8):3301-3306

Rahman S, Hasan MK (2014) Energy productivity and efficiency of wheat farming in Bangladesh. Energy 66:107-114

Rathke G-W, Wienhold B, Wilhelm W, Diepenbrock W (2007) Tillage and rotation effect on corn-soybean energy balances in eastern Nebraska. Soil Tillage Res 97(1):60-70

Roy P, Ijiri T, Nei D, Orikasa T, Okadome H, Nakamura N, Shiina T (2009) Life cycle inventory (LCI) of different forms of rice consumed in households in Japan. J Food Eng 91(1):49-55

Tabar IB, Keyhani A, Rafiee S (2010) Energy balance in Iran's agronomy (1990-2006). Renew Sustain Energy Rev 14(2):849-855

Tabatabaeefar A, Emamzadeh H, Varnamkhasti MG, Rahimizadeh R, Karimi M (2009) Comparison of energy of tillage systems in wheat production. Energy 34(1):41-45
Tandon S, Singh S(2009) Energy balance in conservation agriculture and conventional farming: a comparison. In: Proceedings of 4th World Congress on Conservation Agriculture-February, pp 4-7

Tatlıdil FF, Boz I, Tatlidil H (2009) Farmers' perception of sustainable agriculture and its determinants: a case study in Kahramanmaras province of Turkey. Environ Dev Sustain 11(6):1091-1106

Thapa S (2008) Gender differentials in agricultural productivity: evidence from Nepalese household data, Trento, Italy. Electronic paper. No 13722. pp 1-6

Wood R, Lenzen M, Dey C, Lundie S (2006) A comparative study of some environmental impacts of conventional and organic farming in Australia. Agric Syst 89(2):324-348

World Bank (2007) World development report 2008: agriculture for development. World Bank, Washington

World Bank (2009) Gender in agriculture source book. World Bank, Washington

Yilmaz I, Akcaoz H, Ozkan B (2005) An analysis of energy use and input costs for cotton production in Turkey. Renewable Energy 30(2):145-155

Zhang W-F, Dou Z-X, He P, Ju X-T, Powlson D, Chadwick D, Norse D, Lu Y-L, Zhang Y, Wu L (2013) New technologies reduce greenhouse gas emissions from nitrogenous fertilizer in China. Proc Natl Acad Sci 110(21):8375-8380 